\title{
USING FUSSY ANALYTIC NETWORK PROCESS TO EXPLORE THE FACTORS OF PERFORMANCE HOUSING REFURBISHMENT IN TAIWAN
}

\author{
Peddy Pi-Ying LAI \\ Department of Real Estate Management, National Pingtung University, Pingtung, Taiwan, R.O.C. \\ E-mail:piying@mail.npic.edu.tw
}

\begin{abstract}
Housing policy is one of the major public policies in Taiwan. Since 2006 the cities of Taipei and Kaohsiung have been busy with housing refurbishment as part of the urban policies. However, as for the Kaohsiung housing refurbishment projects, the initial result was somewhat disappointing. Only one out of the twelve applicants who applied for housing refurbishment was subsidized in Kaohsiung; the required subsidy rate for Taipei was also low, 38\%. This paper focuses on the performance analysis of the housing refurbishment policy. This paper will use the FANP method to find the factors that could influenced the performance of the housing refurbishment.

Through empirical analysis, it was found that the success of the housing refurbishment projects are heavily affected by the factors of economic benefit and policy deliverables. We believed that the proper promotion of house refurbishment subsidy, the transparency of information can consolidate the implementation of house refurbishment policy.
\end{abstract}

Keywords: housing refurbishment, performance analysis, FANP (Fuzzy Analytic Network Process), housing policy

\section{INTRODUCTION}

In 2011, Taipei continued to implement "facade renovation" subsidies. Out of the 30 application cases, 21 were approved, with an approval rate of $70 \%$. Kaohsiung City Government's "Face Lift of Building" Plan was promoted and implemented in 2006. During 2011, more than 150 old buildings have received subsidies and have completed the façade renovation. According to the Ministry of the Interior, there are 3.7 million houses that are more than 30 years old in Taiwan in 2014, and the average housing age is 27.66 years in Taipei City, 27.08 years in Kaohsiung 
City and 23.94 years in New Taipei City. Faced with the problems such as old building environment, obsolete equipment, housing leaks, the chipping of exterior tiles, illegal buildings, and illegal occupancies, these showed that housing quality has deteriorated. In addition to concerns over compromised public safety, the city appearance is also affected. In the pursuit of the goal of sustainable lowcarbon urban housing development, through housing refurbishments, the public safety and quality of life in the living environment are expected to be enhanced, thereby achieving sustainable development for a healthier and more beautiful city and enhancing the city's competitiveness.

The current problems of old buildings, involve nothing more than the chipping of exterior walls, housing leaks, hazardous buildings due to earthquakes, functional declines, etc. Hence, the purposes of housing refurbishments are to improve damaged and old buildings, enhance the living quality of the environment, create more jobs, improve the urban economy, enrich city finances, construct green buildings in line with the environmental protection standards, improve the living environment, and to bring together and conduct joint participation with owners of buildings and the general public, create shared interest for the public, promote land use, and so on. At present, targeting the referential indicators of the refurbishment subsidy items, Taipei City and Kaohsiung City governments' subsidies continue to focus on the public safety of the entire environment, with the highest priority given to indicators affecting the overall city appearance, heritability, and visibility.

In view of performance assessment related literatures in the past, the methods adopted for evaluating and analyzing the policy performance indicators generally included: the Analytic Hierarchy Process (AHP), Fuzzy Analytic Hierarchy Process (FAHP), and Data Envelopment Analysis (DEA). In the face of complex policy performance analyses on housing refurbishment, a great deal of thought and the vagueness of uncertainty are involved. Hence, the Fuzzy Analytic Network Process (FANP) was adopted in this study. In addition to taking into consideration the concept of the fuzziness of thought, the interdependent relationship among the assumed influential elements is more in line with the current situation. Moreover, the FAHP possesses more feedback results, which shall serve as a reference for the government when promoting housing refurbishment policies, thus contributing to the enhancement of housing refurbishment performance.

The FANP methodology is a multi-criteria decision-making (MCDM) technique for analyzing the major issues facing uncertainty in housing policy. According to Chang (2014), ANP features for its interdependence and feedback which often employ systematic methods for policy making. Moreover, ANP captures the interdependence of decision criteria and improves the limitation of AHP, 
although ANP is not widely used for tackling MCDM problems in real situations (Saaty 1996).

Sarkis (1998) integrated the environmentally conscious business practice elements and attributes into a strategic assessment and applied ANP using the systems, resulting in the importance of the natural environment in everyday and long-term organizational practice and process at a level that is unparalleled since the start of the industrial revolution. Meade and Sarkis (1998) showed what lies in its linkage of disparate strategic logistics and system issues in a single systematic study framework, ANP not only provides solutions to strategic logistics alternative selection, but also provides a structure for an organization to develop and enhance logistics strategy. Wu and Lee (2007) used ANP to ensure the successful implementation of knowledge management, and raise a critical issue of how companies can better evaluate and select a favorable knowledge management strategy before that implementation. The aim of this paper is to identify and discuss some of the completive factors in ornamental fish industry including prioritizing competitive priorities.

Through the literatures and expert questionnaire surveys pertaining to housing refurbishment, this study explored the indicator weighting index of housing refurbishment and the best policies for enhancing performance. The majority of the questionnaires were personally interviewed. The research analysis is intended to gain an insight into: "Which factors affect housing refurbishment performance?" and "How to evaluate the housing refurbishment performance indicators?" This study not only enables the general public to understand the current situation of housing refurbishment performance, but also provides housing refurbishment performance policies.

\section{LITERATURE REVIEW}

Theoretically, refurbishment of buildings will improve the quality of living environment, but there are few empirical studies on it, especially on housing policy performance (Salga 2005). Why do old buildings need to be improved? Mostly owners are faced with the general dilemma of renovating vs. rebuilding. At present, the carbon dioxide emissions in the world's building energy consumptions account for $30-40 \%$ of the world's total carbon dioxide emissions. In the face of energy efficiency and carbon reduction trend for the sustainable development of houses, many domestic urban renewal cases have abandoned reconstruction and opted for refurbishment instead when engaging in urban renewal through maintenance means. 
Regular building checks and repairs are expected to effectively prolong the life cycle of buildings. Housing refurbishment is conducive to public safety, living environment, and life improvement (Chang 1996). Moreover, they also create economic benefits after housing refurbishment that not only the housing prices and rents will increase, but also the house prices in the surrounding environment will generate spillover effects. At the same time, employment opportunities in related industries will increase (Suet 1999). In addition, through housing refurbishment, the effects of carbon reduction and sustainable housing development can be achieved (Miroslaw and Sally 2010).

Hence, Gorgolewski et al. (2005) pointed out that the energy efficient renovation of existing buildings is an important tool for the reduction of energy consumption in the building sector, the improvement of prevailing indoor thermal comfort conditions and also for the improvement of environmental conditions in urban areas. However, Martinaitis et al. (2004) building renovation projects, whose feasibility is assessed only with regards to energy efficiency, should be considered as the result of an "old attitude". In more recent papers, decisions on economically efficient renovation are adapted to new technology methods: Adeli (1988) applies general theories and techniques of expert systems to construction, Henket (1990) suggests a theoretical model of several modular stages in the decision process, Reddy et al. (1993) offer a frame-based decision support model for building renovation. Raslanas et al. (2006) are to select energy efficient refurbishment measures to encourage significant energy savings as well as housing value enhancement.

However, so far the above studies were concentrated on the development value model and energy efficient renovation. There are few studies on the refurbishment policy performance. Among the past literature dealing with performance indicators, the majority of the decision-making models for reference by decisionmakers were established through the integration of the majority of expert opinions.

In consideration to the numerous factors affecting the housing refurbishment performance, the vague concept is filled with uncertainty, and the interrelated factors that likely exist among the various factors, the Fuzzy Theory combined with the ANP network hierarchical analysis method were adopted. These methods possess feedback results, thus serving as a reference for promoting polices related to the enhancement of housing refurbishment performance. 


\section{RESEARCH METHOD}

In this study, we will use the FANP method to achieve our purpose. FANP is the combination of the Fuzzy Theory and ANP (Analytic Network Process). In 1971, Saaty developed Analytic Hierarchy Process, which is mainly used in decisionmaking problems involving multiple evaluation standards and under uncertain conditions. Saaty (1980) compiled the theory and it was published in book form in the housing market. This theory is applicable for a limited number of feasible plans. Through a set of selection procedures, the relative importance of the attributes can be evaluated, so as to identify the best plan among the feasible plans. The purpose is to: (1) systemize the complex problems; (2) engage in the hierarchical decomposition of different aspects; and (3) reduce the risk of making a wrong decision. Through the above-mentioned methods, large and complex decision-making problems can be decomposed into multiple small sub-problems. Then based on the AHP steps, pair wise comparison and evaluation are conducted before integration, thereby simplifying the complex problems and making it easier to make decisions (see Table 1).

Table 1. Triangular fuzzy conversion scale

\begin{tabular}{lll}
\hline Linguistic scale & Triangular fuzzy scale & Triangular fuzzy reciprocal scale \\
\hline Just equal & $(1,1,1)$ & $(1,1,1)$ \\
Equal importance & $(1 / 2,1,3 / 2)$ & $(2 / 3,1,2)$ \\
Weak importance & $(5 / 2,3,7 / 2)$ & $(2 / 7,1 / 3,2 / 5)$ \\
Strong importance & $(9 / 2,5,11 / 2)$ & $(2 / 11,1 / 5,2 / 9)$ \\
Demonstrated importance & $(13 / 2,7,15 / 2)$ & $(2 / 15,1 / 7,2 / 13)$ \\
Absolute importance & $(17 / 2,9,9)$ & $(1 / 9,1 / 9,2 / 17)$ \\
\hline
\end{tabular}

The FANP methodology is a robust MCDM technique for analyzing the major issues facing uncertainty in manufacturing practices. ANP captures the interdependence of decision criteria and improves the limitation of AHP. Though, ANP is not widely used for tackling MCDM problems in real situations (Saaty 1996). The FANP process is shown as follows:

$$
\begin{array}{cccc}
c_{1} & c_{2} & \ldots & c_{n} \\
e_{11} e_{12} \ldots e_{1 m_{1}} e_{21} e_{22} \ldots e_{2 m_{1}} & \ldots e_{n 1} e_{n 2} \ldots e_{n m_{1}}
\end{array}
$$




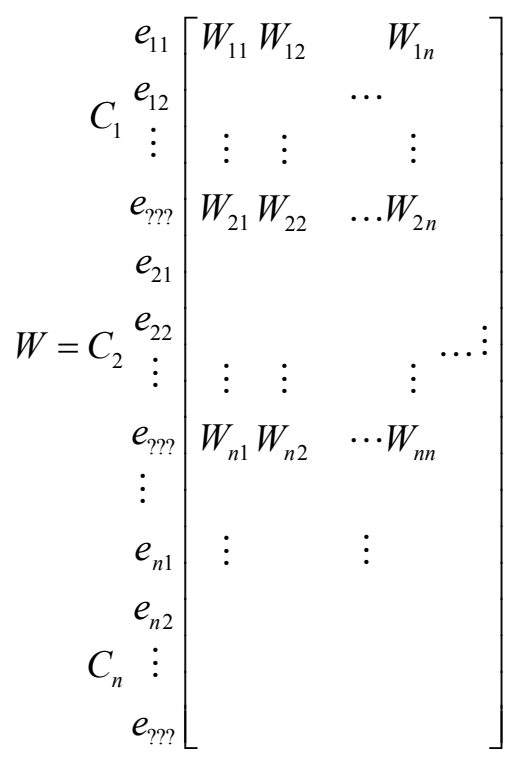

\section{EMPIRICAL RESULTS ANALYSIS}

The recommended policy plans pertaining to housing refurbishment performance assessment indicators and the enhancement of housing refurbishment performance, as well as past literatures on housing refurbishment, focus on the environmental quality of housing refurbishment, public safety, economic benefits, energy efficiency.

To establish greater reliability in the research method, several literatures were used as reference. The discussion and literature reviews have been further prolonged to decide the ten (10) attributes with four (4) criteria to select the three (3) strategies priorities. The following steps have been considered to form the hierarchy (see Figure 1). Therefore, the procedures of our proposed method are mainly divided into four steps as follows:

1. Define the refurbishment performance on selection of indicators priorities.

2. Identify the overall objectives.

3. Identify the criteria, the result that must be satisfied to fulfill the overall objectives, and the interdependency relationships that exist in the attributes level.

4. Structure the hierarchy placing the objective at first level, criteria at second level, attributes at third level and prioritization of performance priorities in housing refurbishment. 


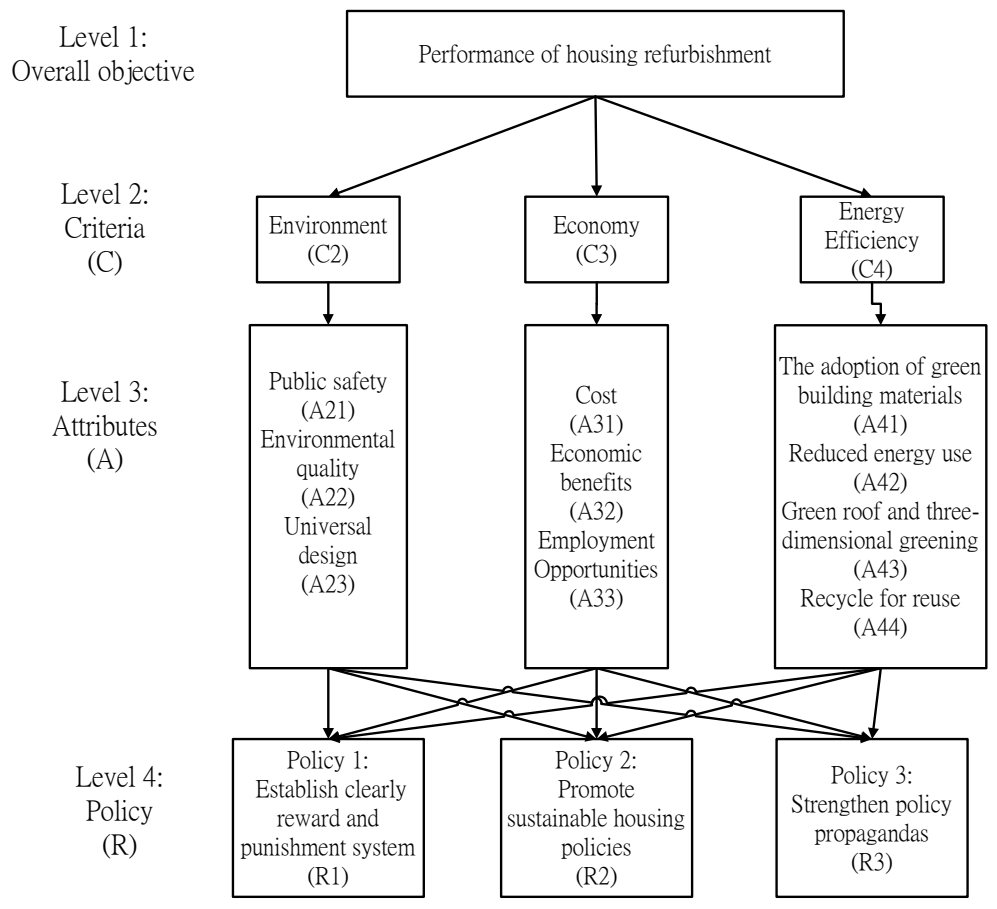

Figure 1. The assessment indicators of housing refurbishment performance and the descriptions of the scope of coverage

\subsection{Charateristics of the respondents}

In this paper, the FANP was conducted in the questionnaire survey for experts and scholars. From the respondents' data compilation, it was found that the majority of the respondents worked in government departments, accounting for $47.69 \%$. The main reason for this is that in the housing refurbishment market, the government departments still play a crucial role. Moreover, the self-assessment method adopted by the government departments is an effective method for exploring the policy performance indicator evaluations; in terms of gender, the respondents were evenly distributed, with males slightly higher than females; in terms of age, the majority belonged to the "21 40 years old" category; in terms of education, the majority belonged to the "graduate school or higher" category, indicating the implementation and evaluation of housing refurbishment require experts with considerable knowledge and experiences. It was also found that the civil servants in the government departments engaged in housing refurbishment undertakings were mostly young with high educational attainment. After all, the promotion and 
implementation of refurbishment related undertakings are laborious and timeconsuming, and communication and coordination are the most important.

As for the respondents' residential area, Taipei and Kaohsiung comprised the majority, mainly because the majority of housing refurbishment related works are in these areas. In terms of the number of years at work, the majority belonged to the " $2 \sim 10$ years" category. The reason for this was that until 2006 the governments departments were engaged in a series of more specific housing refurbishment policy related activities. Related policies have been launched in various places, such as Kaohsiung's Face Lift policy, Taipei's urban renewal, refurbishment, Taipei Beautiful, New Taipei City's refurbishment etc. The majority of the respondents' incomes belonged to the "NT $\$ 20,001 \sim 40,000$ " category, accounting for $47.69 \%$.

Through the ANP pairwise comparison proposed by Saaty, the consistency test was conducted to ensure the validity of the questionnaire results. The consistency index (C.I.) and consistency ratio (C.R.) were both less than the tolerable standard of consistency (C.I. $<0.1$, C.R. $<0.1$ ). CR $0.1 \leq$ is preferred, and the maximum tolerance must not be $>0.2$. Those that fail to reach the standard criteria were eliminated.

The relative weighting was calculated and compiled in Table 2. The research results show that the relative weight of the environment reached $51.3 \%$. Among the assessment indicators of the environment aspect, public safety was given the greatest importance of $51.58 \%$, followed by environmental quality $(31.74 \%)$, and universal design (16.68\%); the economic aspect followed with the relative weighting of $25.21 \%$. Among the assessment indicators, the economic benefits had the highest relative weighting of $43.99 \%$, followed by cost of $32.18 \%$, and employment opportunities of $23.82 \%$; in terms of energy efficiency, it accounted for $23.49 \%$. The relative weights of the 8 assessment indicators under the energy efficiency aspect in order of importance are: reduced energy use (38.96\%), recycle for reuse $(24.59 \%)$, the adoption of green building materials $(19.22 \%)$, and green roof and three-dimensional greening (17.23\%). When measuring the overall absolute weighting, public safety accounted for the majority of $24.46 \%$, followed by environmental quality of $16.28 \%$, and economic benefits of $11.09 \%$. Green roof and three-dimensional greening had the lowest absolute weighting ratio of $4.05 \%$.

After establishing the "housing refurbishment performance" assessment indicators in order of importance, the best decision was selected in this study, as shown in Figure 2. The priority of policy promotions depends on the needs. For instance, if the environment is the main consideration, a clear reward and punishment system should be first established, with the weight of importance reaching $40.59 \%$; if the economy is the main consideration, experts believe that the prioritized consideration should be the promotion of sustainable housing policies, with the critical 
Table 2. The indicator weighting of housing refurbishment through FANP

\begin{tabular}{l|c|l|c}
\hline Evaluation aspect & Relative weighting \% & Assessment indicators & $\begin{array}{l}\text { Relative } \\
\text { weighting \% }\end{array}$ \\
\hline \multirow{2}{*}{ Environment } & \multirow{2}{*}{48.190} & Public safety & 24.96 \\
\cline { 3 - 4 } & & Environmental quality & 15.25 \\
\cline { 3 - 4 } & \multirow{2}{*}{26.91} & Universal design & 7.98 \\
\cline { 3 - 4 } & & Cost & 8.67 \\
\cline { 3 - 4 } & \multirow{2}{*}{ Economy } & Economic benefits & 11.85 \\
\cline { 3 - 4 } & \multirow{2}{*}{ Energy efficiency } & $\begin{array}{l}\text { The adoption of green building } \\
\text { materials }\end{array}$ & 6.37 \\
\cline { 3 - 4 } & & Reduced energy use & 4.67 \\
\cline { 3 - 4 } & & $\begin{array}{l}\text { Green roof and three-dimensional } \\
\text { greening }\end{array}$ & 4.74 \\
\cline { 3 - 4 } & & Recycle for reuse & 6.17 \\
\hline
\end{tabular}

Level 1:

Overall objective

Level 2:

Criteria

(C)

Level 3:

Attributes

(A)

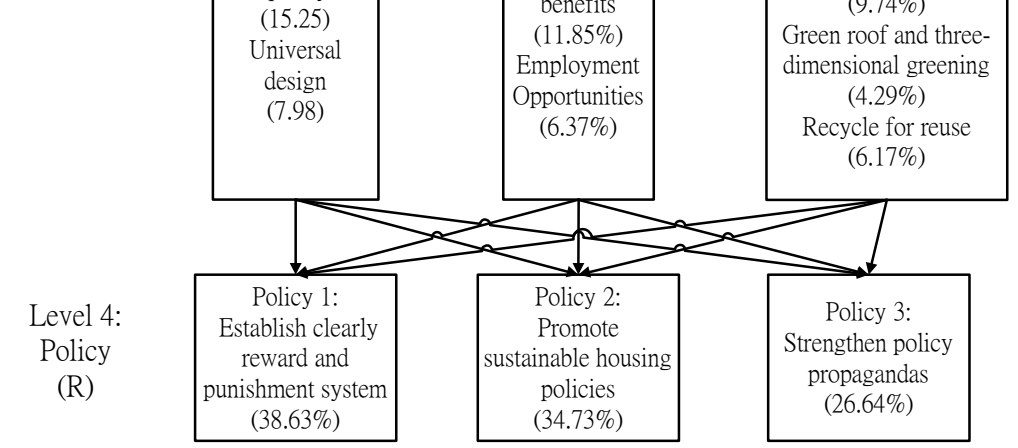

Figure 2. Summary of integration of priority weight to overall objective 
ratio of $38.04 \%$; if energy efficiency is the main consideration, the critical ratio of establishing a clear reward and punishment system is $38.27 \%$. On the whole, in order to enhance the performance of housing refurbishment and maintenance, the most important consideration is the prioritized establishment of a reward and punishment system (38.33\%), followed by the promotion of sustainable housing policies $(34.72 \%)$, and the strengthening of policy propagandas $(26.72 \%)$.

Table 4 shows the limit super matrix compiled from the combination of the different conditions above and targeting the different assumptions and evaluation methods. The Matlab software was adopted to establish the matrix models under research condition. Then, through the self-multiplication of the matrix into convergence, the FANP super matrix was calculated. The FANP limit super matrix through feedback and system integration was adopted.

In Table 3, the results show the priority of policies. If the objective is increasing the performance of housing refurbishment, establishing clearly reward and punishment system is the most important policy. The results are $38.63 \%, 34.73 \%$ and $26.64 \%$ for Policy I, Policy II and Policy III, respectively.

Table 3. The priority of weighted values of the alternative policies

\begin{tabular}{|c|c|c|c|c|c|c|c|}
\hline \multicolumn{2}{|c|}{ Assessment items } & \multirow{2}{*}{ 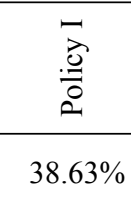 } & \multirow{2}{*}{ 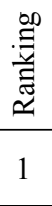 } & \multirow{2}{*}{ 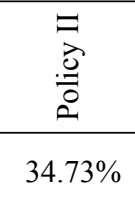 } & \multirow{2}{*}{ 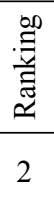 } & \multirow{2}{*}{ 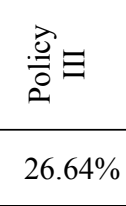 } & \multirow{2}{*}{ 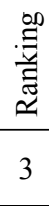 } \\
\hline Objective & $\begin{array}{l}\text { increasing } \\
\text { performance }\end{array}$ & & & & & & \\
\hline \multirow{3}{*}{ Criteria } & environment & $40.71 \%$ & 1 & $33.35 \%$ & 2 & $25.95 \%$ & 3 \\
\hline & economic & $34.66 \%$ & 2 & $38.10 \%$ & 1 & $27.23 \%$ & 3 \\
\hline & energy efficiency & $38.33 \%$ & 1 & $34.15 \%$ & 2 & $27.53 \%$ & 3 \\
\hline \multirow{3}{*}{ Environment } & public safety & $46.01 \%$ & 1 & $29.30 \%$ & 2 & $24.70 \%$ & 3 \\
\hline & $\begin{array}{l}\text { environmental } \\
\text { quality }\end{array}$ & $38.35 \%$ & 1 & $35.88 \%$ & 2 & $25.76 \%$ & 3 \\
\hline & universal design & $37.09 \%$ & 1 & $35.58 \%$ & 2 & $27.31 \%$ & 3 \\
\hline \multirow{3}{*}{ Economy } & cost & $33.92 \%$ & 2 & $38.68 \%$ & 1 & $27.38 \%$ & 3 \\
\hline & economic benefits & $31.19 \%$ & 2 & $41.85 \%$ & 1 & $26.96 \%$ & 3 \\
\hline & $\begin{array}{l}\text { employment } \\
\text { opportunities }\end{array}$ & $30.51 \%$ & 2 & $40.28 \%$ & 1 & $29.20 \%$ & 3 \\
\hline \multirow[t]{4}{*}{$\begin{array}{l}\text { Energy } \\
\text { efficiency }\end{array}$} & $\begin{array}{l}\text { green building } \\
\text { materials }\end{array}$ & $36.28 \%$ & 1 & $36.17 \%$ & 2 & $27.56 \%$ & 3 \\
\hline & Reduced energy & $39.45 \%$ & 1 & $33.00 \%$ & 2 & $27.55 \%$ & 3 \\
\hline & \begin{tabular}{|l} 
green roof \& \\
three-dimensional \\
greening
\end{tabular} & $35.24 \%$ & 1 & $35.21 \%$ & 2 & $29.55 \%$ & 3 \\
\hline & recycle for reuse & $40.40 \%$ & 1 & $30.82 \%$ & 2 & $28.77 \%$ & 3 \\
\hline \multicolumn{2}{|l|}{ Total } & $520.77 \%$ & 1 & $497.10 \%$ & 2 & $382.09 \%$ & 3 \\
\hline
\end{tabular}


Table 4. Evaluation on housing refurbishment in Taiwan

\begin{tabular}{|c|c|c|c|c|c|c|c|}
\hline 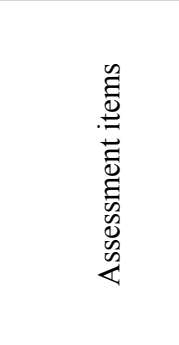 & 离 & 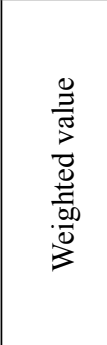 & & 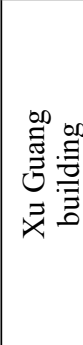 & 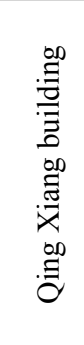 & 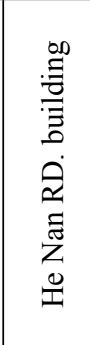 & 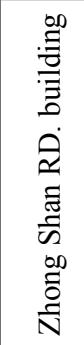 \\
\hline \multirow{9}{*}{ Environment } & \multirow{3}{*}{\begin{tabular}{|l} 
Public safety \\
Environmental \\
quality \\
Universal design
\end{tabular}} & \multirow{3}{*}{$24.96 \%$} & Approve & \multirow{3}{*}{24.96} & \multirow{3}{*}{24.96} & \multirow{3}{*}{24.96} & \multirow{3}{*}{24.96} \\
\hline & & & $\begin{array}{l}\text { Between } \\
\text { approve and } \\
\text { disapprove }\end{array}$ & & & & \\
\hline & & & Disapprove & & & & \\
\hline & \multirow{3}{*}{$\begin{array}{l}\text { Cost } \\
\text { Economic benefits } \\
\text { Employment op- } \\
\text { portunities }\end{array}$} & \multirow{3}{*}{$15.25 \%$} & Approve & \multirow{3}{*}{15.25} & \multirow{3}{*}{15.25} & \multirow{3}{*}{15.25} & \multirow{3}{*}{15.25} \\
\hline & & & $\begin{array}{l}\text { Between } \\
\text { approve and } \\
\text { disapprove }\end{array}$ & & & & \\
\hline & & & Disapprove & & & & \\
\hline & \multirow{3}{*}{$\begin{array}{l}\text { The adoption of } \\
\text { green building } \\
\text { materials } \\
\text { Reduced energy } \\
\text { use } \\
\text { Green roof and } \\
\text { three-dimensional } \\
\text { greening } \\
\end{array}$} & \multirow{3}{*}{$7.98 \%$} & Approve & \multirow{3}{*}{7.98} & \multirow{3}{*}{3.99} & \multirow{3}{*}{0} & \multirow{3}{*}{0} \\
\hline & & & $\begin{array}{l}\text { Between } \\
\text { approve and } \\
\text { disapprove }\end{array}$ & & & & \\
\hline & & & Disapprove & & & & \\
\hline \multirow{9}{*}{ Economy } & \multirow{3}{*}{$\begin{array}{l}\text { Recycle for reuse } \\
\text { Public safety } \\
\text { Environmental } \\
\text { quality }\end{array}$} & \multirow{3}{*}{$8.67 \%$} & Approve & \multirow{3}{*}{8.67} & \multirow{3}{*}{8.67} & \multirow{3}{*}{4.34} & \multirow{3}{*}{4.34} \\
\hline & & & $\begin{array}{l}\text { Between } \\
\text { approve and } \\
\text { disapprove }\end{array}$ & & & & \\
\hline & & & Disapprove & & & & \\
\hline & \multirow{3}{*}{$\begin{array}{l}\text { Universal design } \\
\text { Cost } \\
\text { Economic benefits }\end{array}$} & \multirow{3}{*}{$11.85 \%$} & Approve & \multirow{3}{*}{11.85} & \multirow{3}{*}{11.85} & \multirow{3}{*}{11.85} & \multirow{3}{*}{11.85} \\
\hline & & & $\begin{array}{l}\text { Between } \\
\text { approve and } \\
\text { disapprove }\end{array}$ & & & & \\
\hline & & & Disapprove & & & & \\
\hline & \multirow{3}{*}{$\begin{array}{l}\text { Employment op- } \\
\text { portunities } \\
\text { The adoption of } \\
\text { green building } \\
\text { materials } \\
\text { Reduced energy } \\
\text { use }\end{array}$} & \multirow{3}{*}{$6.37 \%$} & Approve & \multirow{3}{*}{6.37} & \multirow{3}{*}{6.37} & & \\
\hline & & & $\begin{array}{l}\text { Between } \\
\text { approve and } \\
\text { disapprove }\end{array}$ & & & 3.19 & 3.19 \\
\hline & & & Disapprove & & & & \\
\hline
\end{tabular}


Table 4 continued

\begin{tabular}{|c|c|c|c|c|c|c|c|}
\hline 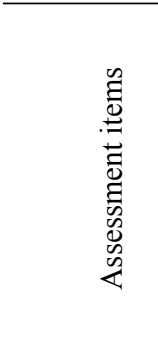 & 离 & 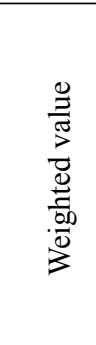 & & 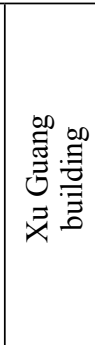 & 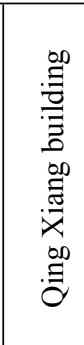 & 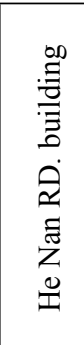 & 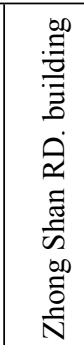 \\
\hline \multirow{12}{*}{$\begin{array}{l}\text { Energy ef- } \\
\text { ficiency }\end{array}$} & \multirow{3}{*}{$\begin{array}{l}\text { Green roof and } \\
\text { three-dimensional } \\
\text { greening } \\
\text { Public safety }\end{array}$} & \multirow{3}{*}{$4.67 \%$} & Approve & \multirow{3}{*}{2.34} & \multirow{3}{*}{0} & \multirow{3}{*}{4.67} & \multirow{3}{*}{4.67} \\
\hline & & & \begin{tabular}{|l|} 
Between \\
approve and \\
disapprove
\end{tabular} & & & & \\
\hline & & & Disapprove & & & & \\
\hline & \multirow{3}{*}{\begin{tabular}{|l} 
Environmental \\
quality \\
Universal design \\
Cost
\end{tabular}} & \multirow{3}{*}{$9.74 \%$} & Approve & \multirow{3}{*}{4.87} & \multirow{3}{*}{4.87} & \multirow{3}{*}{9.74} & \multirow{3}{*}{9.74} \\
\hline & & & \begin{tabular}{|l} 
Between \\
approve and \\
disapprove
\end{tabular} & & & & \\
\hline & & & Disapprove & & & & \\
\hline & \multirow{3}{*}{$\begin{array}{l}\text { Economic benefits } \\
\text { Employment op- } \\
\text { portunities } \\
\text { The adoption of } \\
\text { green building } \\
\text { materials } \\
\end{array}$} & \multirow{3}{*}{$4.29 \%$} & Approve & \multirow{3}{*}{2.15} & \multirow{3}{*}{2.15} & \multirow{3}{*}{2.15} & \multirow{3}{*}{4.29} \\
\hline & & & \begin{tabular}{|l} 
Between \\
approve and \\
disapprove
\end{tabular} & & & & \\
\hline & & & Disapprove & & & & \\
\hline & \multirow{3}{*}{$\begin{array}{l}\text { Reduced energy } \\
\text { use }\end{array}$} & \multirow{3}{*}{$6.17 \%$} & Approve & \multirow{3}{*}{0} & \multirow{3}{*}{0} & \multirow{3}{*}{0} & \multirow{3}{*}{0} \\
\hline & & & \begin{tabular}{|l|} 
Between \\
approve and \\
disapprove
\end{tabular} & & & & \\
\hline & & & Disapprove & & & & \\
\hline \multicolumn{2}{|l|}{ Total credits } & $100 \%$ & & 84.44 & 78.11 & 76.15 & 78.29 \\
\hline
\end{tabular}

\subsection{Cases analysis}

According to the above results, we choose 4 buildings (cases) to test the performance. Table 4 presents the performance of housing refurbishment based on 10 criteria by our empirical results. Xu Guang building was rewarded the best performance of four cases. The second was Qing Xiang building. 


\section{CONCLUSION}

The FANP approach has been presented to select the best indicators for refurbishment performance. The environmental aspect and public safety indicators are the most important assessment indicators for housing refurbishment. As far as the consideration aspect of the importance of housing refurbishment performance indicators is concerned, the most important is the environment. The weighting values in the assessment in order are: environment (51.30\%), economy (25.21\%), and energy efficiency (23.49\%); as far as the housing refurbishment performance indicators are concerned, the most important indicator is public safety $(26.46 \%)$, followed by environmental quality (16.28\%), economic benefits (11.09\%), reduced energy use $(9.15 \%)$, universal design $(8.55 \%)$, cost $(8.11 \%)$, employment opportunities $(6.01 \%)$, recycle for reuse $(5.78 \%)$, the adoption of green building materials $(4.52 \%)$, and green roof and three-dimensional greening $(4.05 \%)$, a total of 10 assessment indicators. In addition, targeting the recommended policies and with the enhancement of the overall performance as the main consideration, the expert opinions were compiled and it is believed that: Policy 1: "Establishing a clear reward and punishment system", which has the greatest importance of $38.55 \%$, followed by Policy 2: "Promote sustainable housing policies" accounted for $34.72 \%$; and Policy 3: "Strengthen policy propagandas" accounted for $26.72 \%$. Based on the different assessment basis points, different policy assessment considerations arise in response to different environmental needs, thereby enhancing the overall housing refurbishment performance.

The FANP is capable of taking into consideration qualitative and quantitative criteria. As the development and evaluation of this model demand significant time and effort from the policy-makers in the formation of pairwise comparison matrices, these should be used for long-term decisions as the refurbishment process is a lengthy and cumbersome one due to the policy-making that is required. However success is achieved in due course of time.

\section{REFERENCES}

Adeli, H. (1988). Expert Systems in Construction and Structural Engineering. New York: Chapman \& Hall.

Andriantiatsaholiniaina, L.A., Kouikoglou, V.S. and Phillis, Y.A. (2004). Evaluating strategies for sustainable development: Fuzzy logic reasoning and sensitivity analysis. Ecological Economics, $48,149-172$.

Blinc, R., Zidanšek, A. and Šlaus, I. (2006). Sustainable development after Johannesburg and Iraq: The global situation and the cases of Slovenia and Croatia. Energy, 31, 2259-2268 
Büyüközkan, G., Ertay, T., Kahraman, C. and Ruan, D. (2004). Determining the importance weight for the design requirements in the house of quality using the fuzzy analytic network approach. International Journal of Intelligent Systems, 19, 443-461.

Chang, D.Y. (1996). Application of the extent analysis method on fuzzy AHP. European Journal of Operational Research, 3, 649-655.

Chang, W.Y. (2014). A study on the key success factors of service quality for international hotels. Acta Oeconomica, 64(Supplement 2), 25-37.

Chau, K.W., Wong, S.K., Leung, A.Y.T. and Yiu, C.Y. (2003). Estimating the value enhancement effects of refurbishment. Facilities, 21(1-2), 13-19.

Chirs and Stephan (2010). Public awareness of green and energy efficient residential property. Property Management, 28(3), 193-208.

Davies, P. and Osmani, M. (2011). Low carbon housing refurbishment challenges and incentives: architects' perspectives. Building and Environment. 46(8), 1691-1698.

Dominique Fischer and Pi-Ying Lai, P. (2008). Land price modeling with genetic algorithms and artificial neural network procedures. 14th Pacific Rim Real Estate Society Annual Conference. Kuala Lumpur (Malaysia).

Eddie, C.M., Hui, J.T.Y., Wong, J. and Wan, K.M. (2008). The evidence of value enhancement resulting from rehabilitation. Facilities, 26, 16-32.

Etaati, L., Sadi-Nezhad, S. and Moghadam, P.M. (2011). Fuzzy analytical network process: An overview on methods. American Journal of Scientific Research, 101-114.

Jharkharia, S. and Shankar, R. (2007). Selection of logistics service provider: An analytic network process (ANP) approach. Omega, 35, 274-289.

Hemphill, L., McGreal, S. and Berry, J. (2004). An indicator-based approach to measuring sustainable urban regeneration performance, Part 2: Empirical evaluation and case-study analysis. Urban Studies, April, 41, 757-772.

Henket, H.A.J. (1990). Choosing an appropriate intervention in existing building: A theoretical model. Proceedings of the International Symposium on Property Management and Modernization, 7(9), 473-482.

Lee, G. K. and Chan, E.H.W. (2010). Evaluation of the urban renewal projects in social dimensions. Property Management, 28(4), 257-269.

Leopoldberger, G., Bienert, S., Brunauer, W., Bobsin, K. and Schutzenhofer, C. (2010). Energizing property valuation in Europe. Putting a value on energy efficient buildings. ERES, 178.

Lin, C.T. and Hsu, V. (2008). Determinants of initial IPO performance: Evidence from Hong Kong and Taiwan. Applied Financial Economics, 18, 955-963.

Mao, J.C.T. (1966). Efficiency in public urban renewal expenditures through benefit-cost analysis. Journal of the American Institute of Planners, 32(2), 95-107.

Martinaitis, V., Rogoza, A. and Bikmaniene, I. (2004). Criterion to evaluate the "twofold benefit" of the renovation of buildings and their elements. Energy and Buildings, 36(1), 3-8.

Meade, L. M. and Sarkis, J. (1998). Strategic analysis of logistics and supply chain management systems using the analytic network process. Logistics and Transportation Review, 34(2), 241261.

Miroslaw and Sally (2010). The Cost-effectiveness of Refurbishing Polish. Housing Stock.

Nihau, E. and Sevil, SS. (2011). Ranking of the GSM Operators with Fuzzy ANP, Proceedings of the World Congress on Engineering, Vol II. London. U.K.

Önüt, S., Kara, S.S. and Işik, E. (2008). Long term supplier selection using a combined fuzzy MCDM approach: A case study for a telecommunication company. Expert Systems with Applications, 36(2), 3887-3895. 
Pi-Ying Lai, P. (2010). The Economic Effect of the Housing Refurbishment in Urban Regeneration. Pacific Rim Real Estate Society Annual Conference, Wellington.

Pi-Ying Lai, P. (2011). The economic effect of the housing refurbishment in urban regeneration. Journal of Modern Accounting and Auditing, 7(1), 31-37.

Promentilla, M.A., Furuichi, T., Ishii, K. and Tanikawa, N. (2008). A fuzzy analytic network process for multi-criteria evaluation of contaminated site remedial countermeasures. Journal of Environmental Management, 88(3), 479-495.

Rajat, G. and Smita, C. (2010). Understanding occupants: feedback techniques for large-scale lowcarbon domestic refurbishments. Building and Research \& Information, 38(5), 530-548.

Raslanas, S., Gulbinas, A. and Tupènaitė L. (2006). Peculiarities on Vilnius multi-storied housing refurbishment from the energy efficiency aspect. Proceedings of the International Conference "Buildings Energy Efficiency in the Baltics. Oct. 25, Riga, Latvia, 176-197.

Reddy, P.V., Socur, M. and Ariaratnam, S.T. (1993). Building renovation decision support model. Proceedings of the ASCE 5th International Conference on Computing in Civil and Building Engineering, Anaheim, 7(9), 1547-1554.

Saaty, T.L. (1988). Decision Making for Leaders: The Analytical Hierarchy Process for Decisions in a Complex World. RWS Publications Inc, Pittsburgh.

Saaty, T.L. (1996). Decision Making with Dependence and Feedback: The Analytic Network Process. RWS Publications: USA., 67-68.

Saaty, T.L. (1980). The Analytic Hierarchy Process: McGraw-Hill.

Salga, J. (2005). The Eastern European workshop on housing finance and housing affordability. Acta Oeconomica, 55(1), 89-93.

Sarkis, J. (1998). Evaluating environmentally conscious business practices. European Journal of Operational Research, 107(1), 159-174.

Semra, B. and Goztepe, K. (2010). Development of a fuzzy decision support system for commodity acquisition using fuzzy analytic network process. Expert Systems with Applications, 37, 19391945

Skibniewski, M.J. and Chao, L. (1992). Evaluation of advanced construction technology with AHP method. J. Constr. Energy and Management. ASCE, 118(3), 577-593.

Spangenberg, J.H. (2002.) Institutional sustainability indicators: An analysis of Agenda 21 and a draft set of indicators for monitoring their effectiveness. Sustainable Development, 10(2), $103-115$.

Spangenberg, J.H. (2004). Reconciling sustainability and growth: criteria, indicators, policies. Sustainable Development, 12, 74-86.

Suet, Y-H. (1999). Evaluation Urban Regeneration Programmers in Britain: Exploring the Potential of the Realist Approach. SAGE Publications, London-Thousand Oaks-New Delhi, 431.

United Nations Commission on Sustainable Development (UNCSD) (2001). Indicators of Sustainable Development: Framework and Methodologies, http://www.un.org/esa/csd9.

$\mathrm{Wu}, \mathrm{W} . \mathrm{W}$. and Lee, Y.T. (2007). Selecting knowledge management strategies by using the analytic network process. Expert Systems with Applications, 32(3), 841-847. 